\title{
Proximate composition and standing crop of Durvillaea antarctica (Pheophyta) in the Bay of Morbihan, Kerguelen (South Indian Ocean)
}

\author{
John M. Lawrence \\ Department of Biology, University of South Florida, Tampa, Florida 33620, USA
}

\begin{abstract}
The proximate composition (\% dry weight) of Durvillaea antartica (Cham.) Hariot was similar for the frond and stipe, being $28 \%$ ash, $3 \%$ protein, ca $1 \%$ lipid, less than $10 \%$ acid-soluble carbohydrate, and $60 \%$ acid-insoluble carbohydrate. The holdfast differed by being $22 \%$ ash and $66 \%$ acid-insoluble carbohydrate. The energetic level of all 3 components was ca $13 \mathrm{~kJ}\left(\mathrm{~g} \mathrm{dry} \mathrm{wt}^{-1}\right.$ and ca $17 \mathrm{~kJ}(\mathrm{~g} \text { ash-free dry } \mathrm{wt})^{-1}$. The relative proportion of the 3 plant components varied little for plants having stipe diameters ranging from 10 to $40 \mathrm{~mm}$, being ca 8,3 , and $89 \%$ wet wt and ca 10,4 , and $86 \%$ $\mathrm{kJ}$ for the holdfast, stipe, and frond, respectively. Maximal density found in summer was 471 individual plants $\mathrm{m}^{-2}, 226 \mathrm{~kg}$ wet $\mathrm{wt} \mathrm{\textrm {m } ^ { - 2 }}$, and $457000 \mathrm{~kJ} \mathrm{~m}^{-2}$. Juvenile plants dominated in terms of individuals, but adults were more important in gravimetric and energetic units. $D$. antarctica allocates most of its biomass and energy to the frond throughout its size range. The characteristics of $D$. antarctica in the Bay of Morbihan are those for a sheltered shore.
\end{abstract}

\section{INTRODUCTION}

The genus Durvillaea is conspicuous in the austral regions because of its formation of a belt (or ceinture) on high-energy rocky shores where its long, floating fronds can reach a length of more than $10 \mathrm{~m}$ (Fritsch 1945). Because it is the dominant primary producer and repository of organic material and energy in this narrow fringe, the biomass of Durvillaea has been measured in New Zealand (Hay \& South 1979), Chile (Santelices et al. 1980), and Marion Island (Haxen \& Grindley 1985). Durvillaea antarctica occurs at Kerguelen (Delépine 1963, Arnaud 1974).

It is important to know the standing crop in terms of energetic as well as gravimetric units. Because of differences in inorganic (water and ash) and organic composition, gravimetric values for different species can vary from energetic values. In addition, energetic values are more useful in trophic analyses. Proximate analysis allows one to know the relative contribution of various organic classes to the energy content of an alga, e.g. the relative amounts deposited in structural and non-structural carbohydrates. This gives insight into the ways in which energy and material produced are used and the form in which they are available to the next trophic level.
The purpose of this paper is to report the proximate composition, the allocation of energy to the various plant components, and the gravimetric and energetic density (standing crop) of Durvillaea antarctica from the Bay of Morbihan, Kerguelen.

\section{MATERIALS AND METHODS}

Individual plants (those with separate holdfasts) were collected in December 1984 along the Promenade des Amerlocks on the north shore of the Bay of Morbihan, Kerguelen $\left(49^{\circ} \mathrm{S}, 70^{\circ} \mathrm{E}\right)$. The diameter of the stipes was measured for regression against the wet weights of the holdfast, stipe, and frond of the plant.

The fronds, stipes, and holdfasts of the plants with stipe diameters ranging from 7 to $40 \mathrm{~mm}$ were separated, weighed, lyophilized, and reweighed. The dried plant material was homogenized in a Wiley mill and the proximate composition measured. Ash was measured gravimetrically by ashing in a muffle-furnace at $500^{\circ} \mathrm{C}$ for $4 \mathrm{~h}$ (Paine 1971 ); $\mathrm{NaOH}$-soluble protein was measured colorimetrically by the biuret method of Gornall et al. (1949); total lipid was measured gravimetrically by the hot chloroform-methanol method of Freeman et al. (1957); trichloroacetic-acid 
soluble carbohydrate was measured colorimetrically by the method of Dubois et al. (1953); insoluble carbohydrate was calculated by subtraction. The number of $\mathrm{kJ}$ ( $\mathrm{g}$ dry tissue) ${ }^{-1}$ of the different plant components was calculated by multiplying the level of each organic class by its caloric equivalent (converted to $\mathrm{kJ}$ ) given by Brody (1945). The total energy content was calculated by multiplying the $\mathrm{kJ}$ ( $\mathrm{g}$ dry $\mathrm{wt})^{-1}$ by the $\mathrm{g}$ dry weight.

The standing crop of Durvillaea antarctica was measured for 4 quadrats along the Promenade des Amerlocks. This was done non-destructively by ascertaining the size (the diameter of the mid-section of the stipe) frequency distribution of the plants in the quadrats. The quadrats encompassed the vertical range of the Durvillea belt and a horizontal range to include at least 100 plants. The biomass and energetic equivalents of the stipes and fronds were estimated from the regression of the components on stipe diameter. The holdfasts were not included because they were frequently contiguous for different plants.

\section{RESULTS}

The wet weights of the holdfast, stipe, and fronds of Durvillaed antarctica are directly related to the stipe diameter and have correlation coefficients of $0.73,0.87$, and 0.65 , respectively (Fig. 1).

The proximate composition for each plant component of Durvillaea antarctica showed little variation (Table 1) indicating that the composition did not vary greatly over the range of plant sizes analyzed. Levels of TCA-soluble carbohydrate, protein, and lipid were similar for the 3 plant components, but the level of ash was lower and the levels of dry weight and TCAinsoluble carbohydrate were higher in the holdfast than in the stipe and frond. Because of the lower level of ash, the energetic level in terms of $g$ dry wt is highest in the holdfast. The differences in organic proximate composition were not sufficient to result in much difference among the plant components in energetic levels in terms of $g$ ash-free dry wt. In both instances, TCA-insoluble carbohydrate contributed 81 to $82 \%$ of the energy content.

The relative proportion of the 3 plant components (in gravimetric and energetic units, calculated from the relations between stipe diameter and component wet weight and proximate composition) varied little with change in plant size (Table 2). The frond was always the largest component, representing 89 to $90 \%$ of the total in terms of wet weight and 84 to $89 \%$ of the total in terms of energy.

The size frequency distribution of Durvillaea antarc-
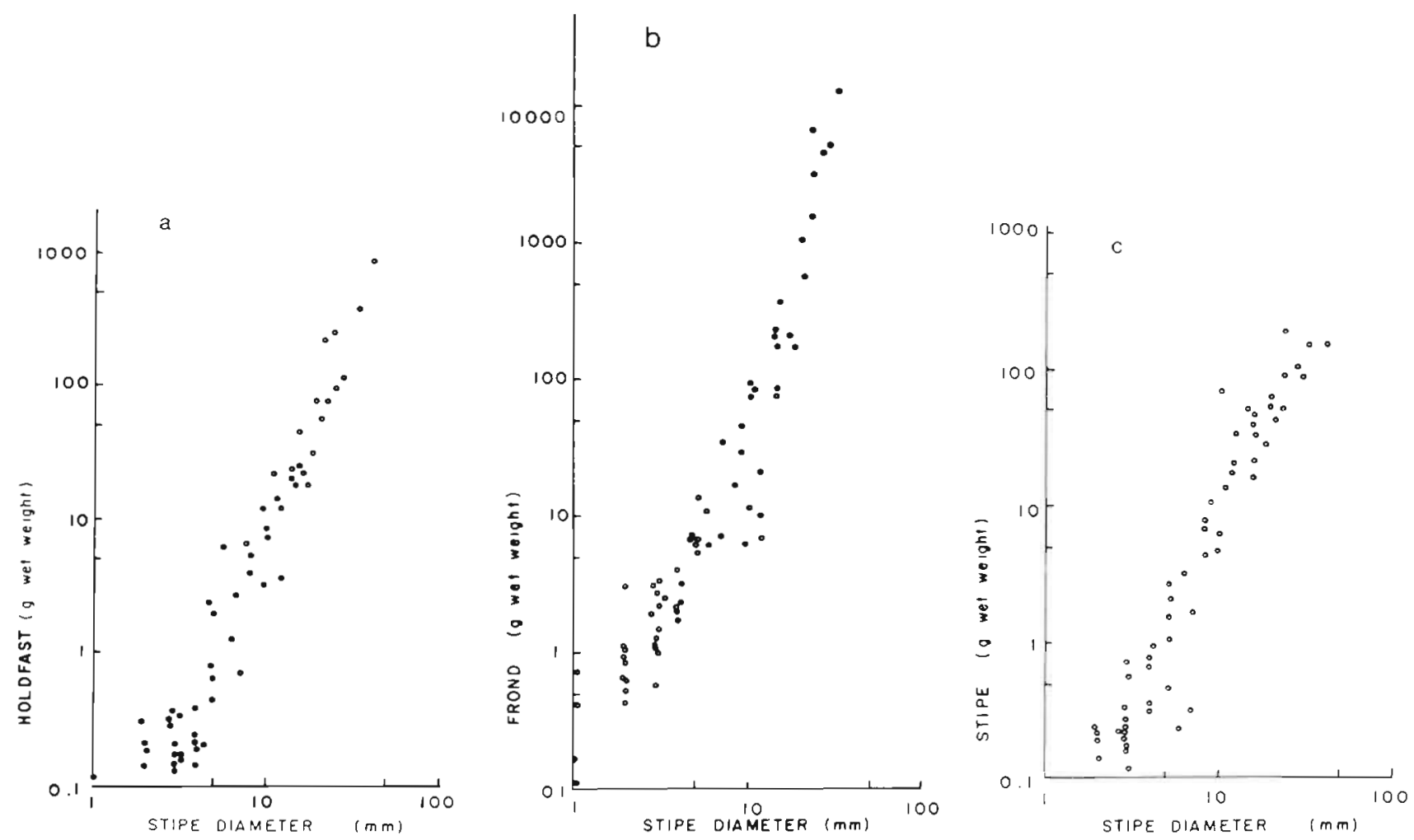

Fig. 1. Durvillaea antarctica. Relation between diameter of the stipe ( $\mathrm{mm}$ ) and the wet weight (g) of (a) holdfast, (b) stipe, and (c) frond 
Table 1. Durvillaea antarctica. Proximate composition and energetic levels of holdfast (H), stipe (S), and frond (F) of samples from Kerguelen in December 1984. Values for dry weight are in terms of wet weight; other proximate values are in terms of percent dry weight. Values for proximate composition are $\bar{x} \pm S D$, except lipid values which are for pooled samples and insoluble carbohydrate which was calculated by subtraction. Values in parentheses are percent of total. $N=10$

\begin{tabular}{|c|c|c|c|}
\hline \multirow[t]{2}{*}{ Constituent } & \multicolumn{3}{|c|}{ Component } \\
\hline & $\mathrm{H}$ & $\mathrm{S}$ & $\mathrm{F}$ \\
\hline \multicolumn{4}{|l|}{ Proximate composition (\%) } \\
\hline Dry weight & $20 \pm 1$ & $16 \pm 2$ & $16 \pm 2$ \\
\hline Ash & $22 \pm 2$ & $28 \pm 3$ & $28 \pm 4$ \\
\hline Protein & $3.3 \pm 0.8$ & $3.3 \pm 0.7$ & $3.4 \pm 1.7$ \\
\hline Lipid & 0.6 & 0.4 & 1.2 \\
\hline Carbohydrate, soluble & $8.6 \pm 2.4$ & $8.0 \pm 2.5$ & $6.5 \pm 2.1$ \\
\hline Carbohydrate, insoluble & 66 & 60 & 61 \\
\hline \multicolumn{4}{|c|}{ Energetic level $\left.(\mathrm{kJ} \text { [g dry wt }]^{-1}\right)$} \\
\hline Protein & $0.78 \quad(6)$ & $0.78 \quad(6)$ & $0.80 \quad(6)$ \\
\hline Lipid & 0.24 & $0.16 \quad(2)$ & $0.47 \quad(4)$ \\
\hline Carbohydrate, soluble & $1.48(11)$ & $1.37(11)$ & 1.11 (9) \\
\hline Carbohydrate, insoluble & $11.32(82)$ & $10.30(82)$ & $10.47(81)$ \\
\hline Total & 13.82 & 12.61 & 12.85 \\
\hline \multicolumn{4}{|c|}{ Energetic level $\left(\mathrm{kJ}[\mathrm{g} \text { ash-free dry } w \mathrm{t}]^{-1}\right)$} \\
\hline Protein & $0.99 \quad(6)$ & $1.09 \quad(6)$ & $1.11(6)$ \\
\hline Lipid & 0.32 & 0.20 & $0.67 \quad(4)$ \\
\hline Carbohydrate, soluble & $1.87(11)$ & $1.89(11)$ & 1.54 (9) \\
\hline Carbohydrate, insoluble & $14.41(82)$ & $14.36(82)$ & $14.51(81)$ \\
\hline Total & 17.59 & 17.54 & 17.83 \\
\hline
\end{tabular}

Table 2. Durvillaed antarctica. Relations between stipe diameter, wet weight, and energy content of holdfast (H), stipe (S), and frond $(F)$ of samples from the Promenade des Amerlocks, Kerguelen. Numbers in parentheses are percentage of total

\begin{tabular}{|c|c|c|c|c|c|c|c|c|}
\hline \multirow{2}{*}{$\begin{array}{c}\text { Stipe } \\
\text { diameter } \\
(\mathrm{mm})\end{array}$} & \multicolumn{4}{|c|}{ Wet weight (g) } & \multicolumn{4}{|c|}{ Energy content $(\mathrm{kJ})$} \\
\hline & $\mathrm{H}$ & $\mathrm{S}$ & F & $\Sigma$ & $\mathrm{H}$ & $S$ & $\mathrm{~F}$ & $\Sigma$ \\
\hline 10 & $10(6)$ & $7(4)$ & $150(89)$ & 167 & $27 \quad(8)$ & $14(4)$ & $307(88)$ & 348 \\
\hline 20 & $100(9)$ & $50(4)$ & $1000(87)$ & 1150 & $276(11)$ & $101(4)$ & $2048(84)$ & 2425 \\
\hline 30 & $400(7)$ & $150(3)$ & $5000(90)$ & 5550 & $1104 \quad$ (9) & $302(3)$ & $10240(88)$ & 11646 \\
\hline 40 & $800(7)$ & $200(2)$ & $10400(90)$ & 11400 & $2208 \quad$ (9) & $403(2)$ & $21292(89)$ & 23910 \\
\hline
\end{tabular}

tica in the 4 stations along the Promenade des Amerlocks is given in Fig. 2. All populations had large numbers of juveniles but were dominated in standing crop (stipe and frond only) by large plants. The densities of $D$. antarctica were high whether expressed in terms of numbers of individuals, $g$ wet weight, or $\mathrm{kJ}$ (Table 3), but the significance of the juveniles is much less when the density is expressed in gravimetric or energetic units.

\section{DISCUSSION}

Except for the higher level of dry weight and TCAinsoluble carbohydrate in the holdfast, the proximate composition of the component parts of Durvillaea antarctica varies little. Similarly, the proximate composition of the different components varies little with plant size. An external cortex is associated with all components, and its composition might differ from that of the inner tissue. The energetic level calculated here for the tissue of $D$. antarctica (ca $13 \mathrm{~kJ}[\mathrm{~g} \mathrm{dry} w]^{-1}$ ) is similar to that $\left(11.1 \mathrm{~kJ} \mathrm{~g}^{-1}\right)$ obtained by calorimetry for juveniles (Haxen \& Grindley 1985).

The TCA-insoluble carbohydrates include alginates, which are precipitated by the acid-extraction procedure. Alginates are 45 to $47 \%$ of the dry weight of the frond of juvenile Durvillaea antarctica and 38 to $45 \%$ of the dry weight of the frond of adults (South 1979). Because the level of TCA-insoluble carbohydrates is the same in fronds of juvenile and adult $D$. antarctica, the frond of adults must contain more non-alginate structural carbohydrates such as cellulose than the frond of juveniles. Alginates are 30 to $35 \%$ of the dry weight of the stipe (South 1979). Because the level of TCA-insoluble carbohydrates is the same in the frond and the stipe, the stipe must contain more non-alginate 


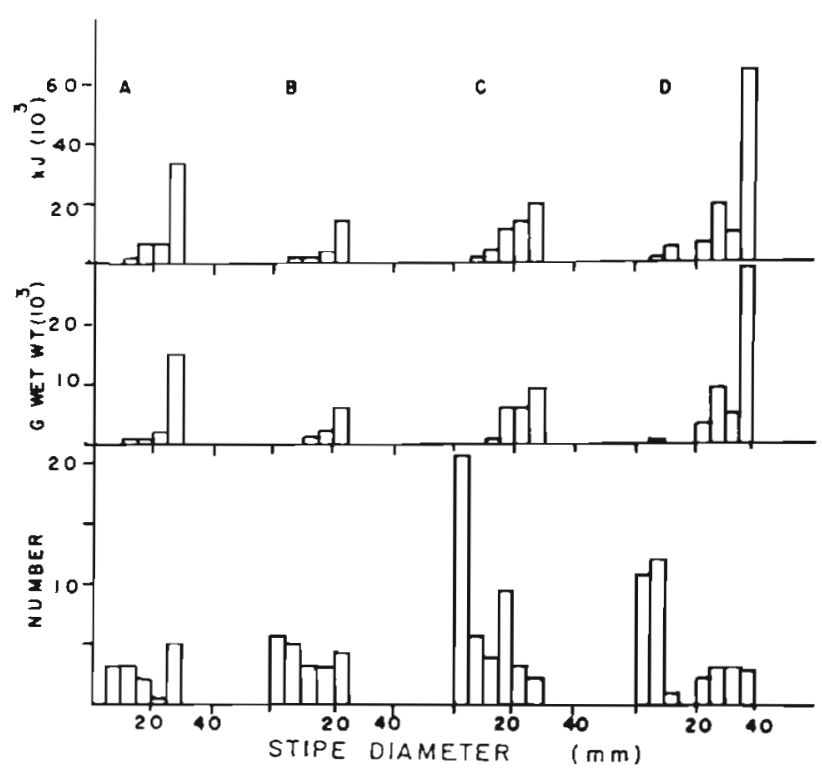

Fig. 2. Durvillaea antarctica. Size frequency distribution of individual plants from 4 quadrats $(A, B, C, D)$ on the Promenade des Amerlocks, Kerguelen in Dec 1984 in terms of numbers of individuals, wet weight $(\mathrm{kg})$, and energy $(\mathrm{kJ})$

structural carbohydrates than the blade. Alginates are only $36 \%$ of the dry weight of the holdfast of Durvillaea potatorum (Cheshire \& Hallam 1985). Because the holdfast of $D$. antarctica is $68 \%$ TCA-insoluble carbohydrate, the non-alginate structural carbohydrates must comprise nearly $30 \%$ of the total dry weight. These calculations indicate that the frond becomes structurally more resistant with an increase in size. The higher levels of non-alginate structural carbohydrates in the stipe and holdfast would be expected for their greater supportive role.

The allometry of growth of Durvillaea antarctica involves an initial rapid increase in stipe length followed by a rapid increase in stipe diameter (Hay \& South 1979). Although the increase in stipe length reaches a plateau, the stipe diameter and frond length continue to increase with time. The size of the holdfast also continues to increase and, at Kerguelen, distinct growth rings are evident. The differences in the times of growth of the stipe length and diameter are complementary because the proportion of the stipe in terms of weight does not change with plant size.

The relative sizes of the 3 different plant components are of interest because they represent the amount of material and energy that are allocated to different functions. Weight is a good indication of the amount of energy present because the organic proximate composition of all components is similar. As a consequence, all 3 components contain ca $13 \mathrm{~kJ}$ [g dry wt $]^{-1}$. The allocation to the holdfast and stipe could be considered to be energy allocated for 'maintenance' functions and that allocated to the frond for 'production' functions. Durvillaea antarctica allocates most material and energy to the frond at all sizes of the individual plant. The effectiveness of the holdfast and stipe as supporting structures results in a lesser amount of material and energy requirement for maintenance. The allocation of energy to the stipe varies with its own allometry of growth. Early growth of the stipe is in elongation, raising the frond above the surface. After a certain stipe length, which varies with conditions (Haxen \& Grindley 1985), the stipe thickens to provide structural support.

Fronds of Durvillaea antarctica are longer and less divided and have shorter stipes at sheltered locations (Haxen \& Grindley 1985). This may affect the amount of material which can be allocated to the frond. The frond of a $D$. antarctica with a stipe diameter of ca 40 mm from the Promenade des Amerlocks has a blade with a wet weight of ca $10.4 \mathrm{~kg}$ while a plant of similar stipe diameter from Chile has a blade with a wet weight of ca $5 \mathrm{~kg}$ (estimated from the regression given in Santelices et al. 1980).

Fronds of Durvillaea antarctica represented 60 to $68 \%$ of the standing crop on exposed shores of Marion Island, while they were 75 to $82 \%$ of the standing crop on sheltered shores (Haxen \& Grindley 1985). Using the criteria of Haxen \& Grindley, the Promenade des Amerlocks in the Bay of Morbihan at Kerguelen would be classified as a sheltered shore, because the frond represents $81 \%$ of the wet weight of individual plants with a stipe diameter of $40 \mathrm{~mm}$ (the frond represents ca

Table 3. Durvillaea antarctica. Numerical, gravimetric, and energetic densities of samples on the Promenade des Amerlocks, Kerguelen in Dec 1984. Gravimetric and energetic values are for stipe and frond only

\begin{tabular}{ccccc|}
\hline Quadrat & $\begin{array}{c}\text { Horizontal } \times \text { vertical } \\
\text { dimensions (Cm) }\end{array}$ & No. of plants $\mathrm{m}^{-2}$ & ${\mathrm{~kg} \text { wet wt } \mathrm{m}^{-2}}$ & $\mathrm{~kJ} \mathrm{~m}^{-2}$ \\
\hline A & $42 \times 31$ & 108 & 147 & 287772 \\
B & $24 \times 28$ & 298 & 133 & 270267 \\
C & $51 \times 20$ & 471 & 226 & 457029 \\
D & $95 \times 30$ & 116 & 173 & 353091 \\
$\mathrm{x} \pm \mathrm{SD}$ & & $248 \pm 172$ & $168 \pm 50$ & $338356 \pm 103146$ \\
\hline
\end{tabular}


$90 \%$ of the total wet weight of plants with a stipe diameter $30 \mathrm{~mm}$ or less).

The highest value for the standing crop of Durvillaea antarctica at Kerguelen was $226 \mathrm{~kg}$ wet wt $\mathrm{m}^{-2}$. This is considerably greater than the maximum of ca $60 \mathrm{~kg}$ wet wt $\mathrm{m}^{-2}$ reported for 2 recolonizing populations in New Zealand or the 18.5 to $33 \mathrm{~kg}$ wet weight $\mathrm{m}^{-2}$ of non-recolonizing populations (Hay \& South 1979). The value is also higher than the ca $162 \mathrm{~kg}$ wet wt $\mathrm{m}^{-2}$ reported for the sheltered shores on Marion (Haxen \& Grindley 1985). The differences probably result from the mode of estimation of standing crop. D. antarctica occurs in a narrow, intermittent fringe along the lower intertidal zone. Consequently, its standing crop in terms of area will be low if large areas, which do not take into account the non-continuous coverage by the alga, are used as the basis for calculation. In the present study, the quadrats encompassed only the vertical height of the Durvillaea belt and a horizontal range of continuous plant cover.

Acknowledgements. This research was supported by National Science Foundation grant DPP-8108992 and by the administration of the Terres Australes et Antarctique Français. I thank C. J. Dawes, J. B. McClintock, and the referees for commenting on the manuscript, and A. Guille of the National Museum of Natural History (Paris) and the administration and personnel at Kerguelen for their assistance.

\section{LITERATURE CITED}

Arnaud, P. M. (1974). Contribution à la bionomie marine benthique des régions antarctiques et subantarctiques. Téthys 6: 467-653
Brody, S. (1945). Bioenergetics and growth, with special reference to the efficiency complex in domestic animals. Reinhold Publishing Corp., New York

Cheshire, A. C., Hallam, N. D. (1985). The environmental role of alginates in Durvillaea potatorum (Fucales, Phaeophyta). Phycologia 24: 147-153

Delépine, R. (1963). Un aspect des études de biologie marine dans les îles australes Françaises. Comité National Français des Recherches Antarctiques (3): 1-22

Dubois, M., Gilles, K. A., Hamilton, J. K., Rebers, P. A., Smith, R. (1953). Colorimetric method for determination of sugars and related substances. Analyt. Chem. 28: 350-356

Freeman, N. K., Lindgren, F. T., Ng, Y C., Nichols, A. V. (1957). Infrared spectra of some lipoproteins and related lipids. J. biol. Chem. 193: 265-275

Fritsch, F. E. (1945). The structure and reproduction of algae. Vol. II. Cambridge University Press, Cambridge

Gornall, A. G., Bardawill, C. J., David, M. M. (1949). Determination of serum proteins by means of the biuret reaction. $J$. biol. Chem. 117: 751-766

Haxen, P. G., Grindley, J. R. (1985). Durvillaea antarctica production in relation to nutrient cycling at Marion Island. In: Siegfried, W. R., Condy, P. R., Laws, R. M. (ed.) Antarctic nutrient cycles and food webs. Springer-Verlag, Berlin, $637-640$

Hay, C., South, G. R. (1979). Experimental ecology with particular reference to proposed commercial harvesting of Durvillaea (Phaeophyta, Durvilleales) in New Zealand. Botanica mar 22: 431-436

Paine, R. T. (1971). The measurement and application of the calorie to ecological problems. Ann. Rev. Ecol. Syst. 2: $145-164$

Santelices, B., Castilla, J. C., Cancino, J., Schmiede, P. (1980). Comparative ecology of Lessonia nigrescens and Durvillaea antarctica in central Chile. Mar. Biol. 59; 119-132

South, G. R. (1979). Alginate levels in New Zealand Durvillaea (Phaeophyceae), with particular reference to age variations in $D$. antarctica. Proc. Int. Seaweed Symp. 9: 133-142 